\title{
Economic Entitlements via Entrepreneurial Conduct? Women and Financial Inclusion in Neoliberal India ${ }^{1}$
}

\author{
K. Kalpana \\ Indian Institute of Technology Madras \\ kkalpana@iitm.ac.in
}

\begin{abstract}
This paper examines the gendered local character of neoliberalism at the household level by focusing on microcredit/finance programs in India. Microfinance promoted by the state as an informal activity targeting women is intended to alleviate income inequalities, even as it contributes to maintaining the world capitalist system. In India the inception of microfinancebased Self Help Groups (SHGs) or peer groups of women savers and borrowers in the 1990s has coincided with a rightward turn towards neoliberal policies of structural adjustment, privatization and economic deregulation. In this paper, I show how Indian policy makers have endeavored to make women's economic entitlements contingent upon their disciplined financial behavior and their willing participation in neoliberal agendas of creating and deepening 'self-regulating' markets at village levels. Drawing on an ethnographic study conducted in a South Indian state, I show that the community level 'neoliberal disciplining' that microfinance entails does not proceed without resistance. Whilst SHGs seek to constitute women as fiscally disciplined savers and borrowers, women stake their 'rightful' entitlement to bank credit even as they reject outright the entrepreneurial subjectivities they are expected to assume. They pursue purposes and ends that extend well beyond 'financial inclusion.'
\end{abstract}

Keywords: Microfinance, Women, Neoliberal Governmentality, Capitalist Accumulation, India

The intertwining of neoliberal capitalism and development policymaking in the last two decades of the twentieth century and beyond is perhaps best exemplified by the case of microfinance/credit programs. Microfinance programs - which involve neighborhood-based peer groups that save and rotate small amounts of capital and subsequently 'leverage' the resources of formal financial institutions in order to on-lend larger sums of capital to group members (Pagura and Kirsten 2006)- have won powerful adherents and supporters that include international financial institutions such as the World Bank and the International Monetary Fund (IMF), the international development industry (including United Nations agencies), national governments, commercial banks and other for-profit lending institutions. Microfinance is celebrated for having dramatically expanded the "frontier of formal finance" by moving it "down market," or towards "small farmers, micro-entrepreneurs, small and

\footnotetext{
${ }^{1}$ I thank Mangala Subramaniam and two anonymous reviewers for their insightful comments on my paper. I also thank Mangala Subramaniam for having encouraged me to contribute to the special volume and for guiding me through the process of writing for the JWSR.
}

This work is licensed under a Creative Commons Attribution 4.0 United States License. Journal of World-Sy stems Research, Volume 21, Number 1, Pages 50-68, ISSN 1076-156X 
medium enterprises, the very poor and those in remote areas" (Von Pischke 2003: 6-7). In so doing, it contributes to "rural financial deepening," or an expansion in financial transactions in rural areas through the offer of new contract terms and conditions and a wide range of financial services to broader clienteles (Gonzalez-Vega 2003).

The microfinance phenomenon epitomizes what world-systems theorists identify as capital's imperative to seek profit, to endlessly accumulate itself, in the process generating "a need for constant technological change, a constant expansion of frontiers - geographical, psychological, intellectual, scientific" (Wallerstein 2004: 2). Insofar as microfinance is concerned, the emergence of novel transactional technologies that entail innovations in lending and repayment methodologies have set it apart from an older generation of rural credit programs. Some of these innovations include the peer pressure mechanisms inherent to group-based or joint-liability lending that deliver on-time repayment and close-to-market rates of interest typical of most programs. Compared to individual-targeted lending, these programs significantly reduce transaction costs and labor expended by lending institutions in disbursing loans, monitoring loan use or inducing loan repayment (Johnson and Rogaly 1997: 38-51, Wenner 1995). Formerly deemed credit-unworthy, low-income households and communities have come to be perceived not only as 'bankable' but a vast market of savers and borrowers and consumers of financial services waiting to be tapped at the "bottom of the pyramid" (Prahalad 2005).

The global ascendance of microfinance signals an enormous commercial and governmental investment in the quotidian disciplining and responsibilizing of its program participants, in keeping with the imperatives of capital accumulation under neoliberal capitalism. As is well known by now, this disciplining is gendered: women from land-poor and low-income households are the overwhelming constituency of microcredit projects worldwide. Feminist scholars have observed that the valorizing of the economic agency of women in poverty proceeded apace with the advance of neoliberalism in the $1980 \mathrm{~s}$, and they raised growing concerns about the devastating social impacts resulting in the $1990 \mathrm{~s}$. In response to both 'anti-poverty' and 'efficiency'-related concerns, women came to be constructed as a valuable and under-utilized resource for development or the "missing link" (Razavi 1997) in low-cost poverty alleviation strategies. Their participation was expected to deliver optimal outcomes such as enhancing household wellbeing, ensuring child survival, increasing food security, and raising family incomes (Jackson 1996; Razavi 1997).

In this paper, I examine ongoing strategies of capital accumulation in the world economy via feminized and poverty-targeted economic development programs in India. I situate these with respect to transnational processes, such as neoliberal Structural Adjustment Programs, SAPs, and transnational development interventions, such as microfinance, which have flourished in India and elsewhere in consonance with the SAPs. Even as I draw upon theoretical debates that tease out the relationship between microfinance and capitalist accumulation (Aitken 2010; Karides 2010; Karim 2011; Mayoux 2002; Rankin 2001; Weber 2002), I situate these with respect to analytical literature on the Indian experience of neoliberal reforms (Chatterjee 2008; Corbridge et al 2011; Harriss 2011) and the Indian variant of the global microfinance phenomenon viz., Self Help Groups (SHGs) or villagelevel microfinance-centered peer groups. I do so in order to explore the irreducibly specific and particular forms that transnational strategies of capital accumulation may acquire in varied country contexts. 
In India, SHG-based microfinance is currently the most visible and successful embodiment of the 'mainstreaming' of women within economic development and antipoverty programs. ${ }^{2}$ In this paper, I show how women's participation in economic development projects is solicited, mobilized, and harnessed by policy makers as part of the social safety net of hou

seholds in poverty during a period in which the Indian state has transited from a 'developmental' to an 'emergent capitalist' state (Vasavi and Kingfisher 2003). I argue that while an emergent neoliberal state in India extends survival-oriented financial assistance to poor households (via their responsibilized women members), it simultaneously advances neoliberal agendas of creating and deepening self-regulating markets at the grassroots. Drawing upon ethnographic field work conducted in the South Indian state of Tamil Nadu, I explore the contradictions and the unintended outcomes that ensue when rural women, the intended instruments of this process, subvert and re-define project goals and objectives. I use these narratives of subversion to make the case that projects of 'financial governance' that bring a financial rationality to bear on the domains they seek to govern are neither stable nor uncontested, and that we would do well to understand finance itself (and microfinance as part of it) as an assemblage that draws on diverse materials in ways that are often politically contested (Aitken, 2010).

\section{Theorizing Microfinance Under Neoliberal Capitalism: "Self-regulating" Markets and Political safety Nets}

The poor themselves can create a poverty-free world.... Credit can create selfemployment instantaneously. Why wait for others to create a job for you? (Yunus 2005).

As articulated by Grameen Bank founder Muhammad Yunus and others, globally dominant microfinance imaginaries valorize entrepreneurial individuals as responsible agents of their own economic well being. This has taken place even as budget-constrained governments implementing neoliberal economic reforms struggle to provide access to social services and livelihood opportunities for economically marginalized citizenry (Rankin 2001; Mayoux 2002). Analysts note that the massive expansion of microfinance and micro-enterprise based development interventions occurred in the $1990 \mathrm{~s}$ - a period marked by the articulation of a 'poverty agenda' by the global development industry in response to the resurgence of poverty and income inequalities associated with neoliberal economic restructuring (Thomas 2000; Weber 2002). Microfinance was promoted as the grassroots dimension, or the 'human face' of economic liberalization policies and an ideal 'self-help' strategy that would enable the poor to secure services such as education, health, water and sanitation despite increased unemployment and rising costs of basic amenities (Mayoux 2002).

Situating microfinance in the historical context of crisis management in capitalist societies at the turn of the $20^{\text {th }}$ century, Weber (2002) uses Karl Polanyi's (1957) thesis of the "double movement" to argue that neoliberal policy reforms, which may be seen as representing the tendency of capitalism to dis-embed the economy from society by permitting the free market to 'self-regulate' (the 'first movement'), have provoked popular resistance at local levels in several countries undergoing structural reforms (the 'counter-process' or the

\footnotetext{
${ }^{2}$ By late March 2013, over 7.3 million SHGs (of which 81\% were women's SHGs) maintained savings worth Rs. 82 billion (equivalent to approximately US $\$ 1.4$ billion) with the banking sector in India. Of these SHGs, over 4.4 million SHGs (of which 84\% were women's groups) had loans outstanding from banks worth Rs.394 billion (NABARD 2013).
} 
'second movement'). In this context, the "strategic embedding" (Weber 2002) of microfinance in the global political economy of poverty reduction serves the dual function of advancing the goals of the 'first movement' (by extending trade in financial services at the grassroots), even as it acts as a "political safety net" by financing and promoting private entrepreneurship, thereby absorbing surplus labor in informal sectors and mitigating income insecurity. Through its latter role, it simultaneously dampens, contains, and disciplines the politics of the 'second movement' (Weber 2002).

The structural compatibilities between microfinance-based development interventions and economies undergoing neoliberal reform are further developed by Karides (2010) who observes that public assistance to low-income populations in the Caribbean region has increasingly taken the form of support for petty market operations, which was vigorously promoted during the SAPs. In effect, two historic and distinct strategies aiming to overcome the crisis of capitalism — namely governmental transfer and informal self-employment - have fused into the single form of 'micro-enterprise development' that has come to be perceived as a 'safety net under globalization' (Karides 2010). While Weber (2002) and Karides (2010) have underscored the "palliative" relief that microfinance programs offer to populations impacted adversely by neoliberal economic re-structuring, others have argued that microfinance itself may be seen as a "financial object" capable of generating and sustaining forms of profit and capital accumulation (Aitken 2010). To attract international investors specialized financial services providers and Microfinance Institutions (MFIs) often charge their borrowers interest rates that are as high or even significantly higher than rates in the formal financial sector. This distorts the agenda of 'financial inclusion' of the poor, entrenching a 'two-tier' system of credit wherein marginal groups are marked out for highcost credit (Aitken 2010).

The above-mentioned frameworks help us understand the 'strategic embedding' (Weber 2002) of microfinance in the gendered political economy of anti-poverty initiatives in India. I also seek to identify the precise mechanisms of capital accumulation via SHG-based microfinance by showing how the extension of trade in financial services has opened up new disciplined and feminized markets of micro-borrowers and savers for the formal financial sector in India. I examine also whether the "second function" of microfinance (Weber 2002) that is the promotion of private entrepreneurship, or the agenda of 'micro-enterprise development' - actually alleviates income inequality by absorbing surplus labor and enabling women of working poor households to participate in and contribute to capitalist accumulation projects at the grassroots.

While I situate my analysis of microfinance with respect to India's experience of neoliberal economic reforms, I draw on Foucaultian scholars of governmentality who conceive of neoliberalism not so much as a withdrawal or 'retreat of the state,' but as a positive technique of government that spawns new regulatory technologies seeking to govern economic life. By acting upon diverse and multiple social forces and entities (individuals, households, collectives, businesses), the state autonomizes and responsibilizes these so that they may, in turn, regulate and align the conduct of governed populations with broader sociopolitical objectives (Burchell 1996; Rose 1999:174). I propose that microfinance is an emergent regulatory technology of neoliberal governmentality whose rise (in India as well as other parts of the world) coincides with and is, in part, reliant on modes of government that Ferguson and Gupta (2002) describe as "transnational governmentality." Key elements of these global governance regimes include the regulatory and disciplining strategies of SAPs implemented by International Financial Institutions, the proliferation of voluntary organizations supported by transnational funding, and the outsourcing of the functions of the state to non-state actors and agencies that assume responsibility for delivering an array of basic amenities and services to governed populations (Ferguson and Gupta 2002). 
To understand how pivotal the responsibilizing and disciplining of women is to these processes, I turn to literature that explores the making of new gendered subjectivities in keeping with the emergence of neoliberal developmental rationalities. Drawing on their ethnographic research in Nepal and Bangladesh respectively, Rankin (2001) and Karim (2011) argue that microfinance programs attempt to constitute 'rational economic woman' or women clients who function efficiently and sustainably as 'self-maximizing entrepreneurs' (Rankin 2001), embodying the principles of competition, profit, and entrepreneurship and acting in consonance with market rationalities (Karim 2011). It appears then that 'women in poverty' must re-fashion themselves in order to populate the new grassroots level 'selfregulating' markets for microfinance that peer-group based lending has opened up in several parts of the world.

\section{Microfinance Origins and Organizational Specificities in India}

In the decades following India's independence, the post-colonial state adopted the mandate of eliminating the monopoly of the traditional moneylender in rural India and ending the exploitative ties binding the landlord-cum-moneylender to the cultivator-borrower (Pulley 1989). Literature on chronic debt in the rural countryside has shown that indigenous moneylenders accumulated capital through relations of monopoly power and social control over poor cultivators and sharecropper households, enabled by the interlocking of credit with other factor markets such as product and labor markets (Bhaduri 1973, 1986). During the years of 'social banking' (1969 - end-1980s), the central government launched an aggressive, supply-led approach to rural credit, primarily through nationalization and the ensuing mobilization of commercial banks in the cause of wealth redistribution and affirmative action (Pulley 1989). The rural banking initiatives launched during these years included the massive proliferation of bank branches in semi-urban and rural areas, the introduction of specialized lending schemes, the capping of interest rates for specific classes of borrowers, and the setting of targets to lend to designated 'priority' sectors of the economy or 'weaker sections' of the population.

However, the intended linkages between banks and the land-poor or the poorest sections of rural India were stymied by the high transaction costs of doing business with a geographically dispersed population, the "urban orientation" of field staff, and perceptions of the bank as an "alien institution" inaccessible to the poor, among other reasons (NABARD 1999: 1.7.2). The unwillingness of banks to lend to rural population groups in the premicrofinance era, despite policy mandates to do so, is not unique to India, as the literature on rural finance testifies (Hulme and Mosley 1996). Since the advent of microfinance and peergroup based lending, commercial banks and specialized microfinance institutions are willing and eager to lend to informal grassroots collectives in low-income rural and urban settlements leading to the critique of capital accumulation by microfinance lenders as discussed above (Aitken 2010). However, we must attend more closely to the organizational structuring of SHG-based microfinance in India in order to better understand the processes at play.

Residence-based groups that range from 12 - 20 members each, SHGs are grassroots collectives that generate their own capital and take collective decisions with respect to the terms of their financial transactions, such as rates of saving, interest rates, repayment schedules, and disciplinary mechanisms. Promoter agencies - both state and non-state such as non-governmental organizations (NGOs)-facilitate the formation of SHGs and play a supportive role through the provision of training, assistance in accounts-maintenance, financial auditing, and other critical services. As soon as it is formed, an SHG opens a savings account in a proximate commercial bank as the first step in establishing a relationship 
with the formal banking sector. The group leaders, selected from within the group, assume responsibility for maintaining group accounts and liaising with banks, promoter NGOs, and government agencies. Being user-owned and member-controlled entities, SHGs have been described as "micro-banks" (Harper 2002) or "Community-Managed Loan Funds" (Murray and Rosenberg 2006). It is important to note that in this model of lending, the total capital generated within the group through member savings (including interest incomes) belongs to the group and is usually distributed among group members at the end of a stipulated, mutually determined period of time.

While SHGs own the internal finances they generate and make group-level decisions regarding the terms of lending and borrowing, they also borrow from external sourcesprimarily the commercial banks that are the account-holders of the groups' finances. In 199091, the Reserve Bank of India (RBI) and the National Bank for Agriculture and Rural Development (NABARD), the prime institution promoting agricultural and rural financing in India, initiated the SHG-bank linkage project that linked residence-based peer groups to commercial banks so that the resources of the latter are optimally utilized by sections of the rural population (hitherto) un-served by public sector banks. SHG-banking offers nonsubsidized credit linked to the volume of group savings, which the poor can use for any purpose, including household consumption (RBI 2009: 2-4).

In April 1999, the central government introduced a nationwide poverty alleviation program called the SwarnJayanti Gram Swarozgar Yojana (SGSY), which used SHGs to deliver a mix of bank credit and government subsidy to targeted beneficiaries below the official poverty line to encourage self-employment activities. The rural development administration (the District Rural Development Agency at the district level and the Block Development Office at the sub-district or block level) provided the subsidy component of the scheme, while loan funds were provided by commercial banks. Being a targeted anti-poverty intervention that focused on vulnerable sections of the rural poor, the SGSY guidelines prescribed that Scheduled Castes and Scheduled Tribes must account for at least $50 \%$, women $40 \%$ and the disabled $3 \%$ of its total beneficiaries ${ }^{3}$ (RBI 2011).

Apart from the policy push towards SHG-banking by the highest strata of financial policy makers in India, does SHG-banking also make sense to the banking sector from the point of view of enhancing its financial performance and capital accumulation strategies in the neoliberal era? In the following section, I discuss this issue.

\section{Situating Microfinance in Neoliberal India: Why Lend to SHGs?}

Significantly, the enthusiastic promotion of women-targeted microfinance programs since the early 1990 s has coincided with the Indian government's adoption of liberalization policies consisting of the standard IMF/ World Bank policy prescription of short-term stabilization and medium and long-run structural adjustment measures. While some states in the worldsystem have entirely resisted the adoption of neoliberalism, as Subramaniam (2015) points out in her introduction, India has embraced economic liberalization. As Gupta and Sivaramakrishnan (2011) observe, the relationship between economy and state has been reformulated in wide-ranging ways, besides also transforming India's perception of itself and its place in the world-system. In addition to reforms aiming at the international integration of the Indian economy through changes in taxation, trade barriers and investment, a spate of internal changes have facilitated the entry of private operators in core sectors that include

\footnotetext{
${ }^{3}$ The Indian government classifies the Scheduled Tribes (STs), Scheduled Castes (SCs) and the Other Backward Classes (OBCs) in decreasing order of social oppression and deprivation.
} 
health care, education, transport, telecommunications, sanitation, and energy (Gupta and Sivaramakrishnan 2011).

Since the $1990 \mathrm{~s}$, reforms in the Indian banking sector were also undertaken as a component of the overall economic policy reforms, following the recommendations of the first Narasimham Committee on Financial System set up in August 1991. Critics observe that the reforms emphasized improvement of the allocative and financial efficiency of the banking sector, with performance evaluation criteria of the banks shifting towards restoring profitability and portfolio quality above other indices (Kohli 1997). However, the trajectories of neoliberal reforms have been mediated by a strong state tradition (Harriss 2011) in India and path dependencies (Corbridge et al 2011) that have tempered the effects and consequences for different sections of the population. Following from his early work suggesting that the post-colonial Indian state derives its legitimacy by steering the program of economic development and national regeneration, as opposed to the "alien," "extractive" colonial state (Chatterjee 1998), Partha Chatterjee (2008) contends that the growing hegemony of corporate capital in India during the $1990 \mathrm{~s}$ and the ongoing primitive accumulation of capital dispossesses subaltern classes and necessitates welfarist policies targeted to the poor in the electoral/political context of a representative democracy. The recognition that the marginalized may become 'dangerous classes' if left utterly bereft of state support is reflected in the continuance of governmental policies that seek to "reverse the effects of primitive accumulation" (Chatterjee 2008: 62).

Projects of 'inclusive banking' that originated in the early 1990s have thus taken shape in a policy context marked, on the one hand, by the banking sector's pursuit of institutional viability in a competitive and deregulated environment and, on the other, the governmental imperative of complementing the newly-unfettered market mechanism. Apart from the policy push that motivated nationalized banks to finance SHGs, the 'efficiency' considerations of enhancing repayment performance, reducing transaction costs for the lender and restoring the institutional viability of the financing banks (especially India's rural development banks or Regional Rural Banks that had displayed several operational inefficiencies in the past) have also accounted for the vigorous promotion of SHG-financing within the formal financial sector. ${ }^{4}$ Notably, SHG-banking in India was conceived and initiated after the notion of "women as disciplined borrowers" had gained the status of a development truism, following the proliferation of women-targeted microcredit programs in neighboring Bangladesh during the $1980 \mathrm{~s}$. It is hardly incidental, therefore, that the overwhelming participation of women in SHGs was enthusiastically welcomed by financial policy-makers during a period when considerations of commercial viability and transactional efficiency came to dominate the banking sector.

\section{Linking Economic Entitlements and Entrepreneurial Conduct: Microfinance and Neoliberal Governmentality}

In India and elsewhere finance (and microfinance) is not governed in relation to a single set of interests, but is marked instead by complicated networks of social actors and assembled from diverse materials in ways that are often contested (Aitken 2010). On the one hand, the RBI and NABARD have endeavored to mold SHG-banking in keeping with the commercial principles of banking and the guidelines generally identified as best practices in microfinance, such as the avoidance of capital subsidies, non-directed or untied lending, and

\footnotetext{
${ }^{4}$ The first NABARD-issued circular on the SHG-Bank Linkage project expresses these concerns clearly (NABARD 1992).
} 
linking loan size to group savings. On the other hand, the Ministry of Rural Development has sought to use SHGs as cost-effective channels for reaching a subsidy-bearing anti-poverty scheme to a targeted population group for the pre-determined purpose of financing enterprise activity. The multiple and conflicting motives and interests of the different institutional actors involved may be attributed, in part, to the legacies of state developmentalism in India. While the SHG phenomenon emerged and grew during the reform years in India, the linkage of the SHGs to nationalized or state-owned banks and, in particular, their incorporation within central government sponsored anti-poverty schemes have been facilitated by pre-existing state tradition (Harriss 2011) and path dependencies (Corbridge et al. 2011) of 'social banking' in the sector of rural and agricultural financing.

While SHG-banking therefore makes it possible for women from 'unbanked' rural households and communities to lay claim to development resources earmarked for them by policies of the Indian state, this access nevertheless hinges on the women constituting themselves as fiscally disciplined actors - prudent savers and responsible borrowers-in village-level markets for microfinance that the SHG phenomenon has opened up and on their acquisition of the appropriate subjectivities. For instance, an SHG that had functioned for a minimum period of six months was eligible to seek a linkage loan, provided it demonstrated "financial discipline," "credit history," and "mature financial behavior" through the rotation of the group's internally generated financial corpus. Rural women were expected to "imbibe the essentials of financial intermediation" (NABARD 2006: 2) and provide manifest evidence of their "creditworthiness" so that commercial banks may finance them through the Direct Linkage scheme. In order to secure financial assistance through the SGSY scheme, women members of SHGs were required to display entrepreneurial agency by demonstrating willingness and capacity to initiate enterprise activity, besides cultivating proper financial intermediation skills (as in the case of the Linkage scheme).

SHG-based microfinance thus offers a safety net (Karides 2010; Weber 2002) for households in poverty or those belonging to the potentially "dangerous classes" (Chatterjee 2008) through the provision of low-cost bank credit for consumption purposes (via the Linkage scheme) and subsidy-bearing credit for initiating new income-generating activities (via the SGSY scheme). However, in order to avail of the promised financial assistance, the women members of SHGs must undertake to efficiently manage their "micro-banks," create and deepen "self-regulating" markets for microfinance at village levels, and inculcate the skills and capacities required to inhabit these market spaces, advancing thereby the goals of capital accumulation (e.g., Weber 2002). We see, therefore, how SHG-based microfinance, as an emergent technology of neoliberal governmentality, strives to shape and direct the "self-regulating capacities" and "self-steering mechanisms" (Miller and Rose 1990) of women of rural poor households so that they responsibly manage the financial resources they generate, 'choose' to adopt financial calculations, practices and identities in domains where these logics may not have been dominant earlier (Aitken 2010), and willingly bear the risks of collectively-managing micro-enterprise activities.

In the following sections of the paper, I draw on case studies from the state of Tamil Nadu that highlight the processes of negotiation between the women's SHGs, on the one hand, and bankers and the rural development bureaucracy, on the other, when the women stake claim to their economic entitlements (via subsidy-bearing and non-subsidized loan schemes). 


\section{A Note on the Field Study: Rationale and Methods}

While the operational guidelines of the SGSY scheme and the NABARD and RBI-promoted Direct Linkage scheme apply uniformly across the country, the SHG phenomenon has displayed marked regional variations and unevenness in its growth. The two Southern states of Tamil Nadu and Andhra Pradesh assumed an early lead in the program and accounted for $44 \%$ of all credit-linked SHGs by late March 2005, with the four Southern states accounting for 59\% of all credit-linked SHGs in the same period (NABARD 2005: 41).

The ethnographic study this paper draws upon was conducted in two phases between August 2004 and April 2006. The first phase included interviews with a total of 12 NGOs active in SHG promotion in six districts of Tamil Nadu. The second phase consisted of intensive fieldwork involving 27 SHGs in three villages in a district of Northern Tamil Nadu. ${ }^{5}$ In these villages, women from land-poor households - the principal constituency of the SHGs - performed daily wage labor in agriculture, brick kilns, the construction sector, leather-based industries (shoe companies and tanneries), domestic work in wealthier households, and subsistence-level self-employment activities in the lower end of the informal sector. The fieldwork included participant observation of the weekly village-level SHG meetings, multiple rounds of open-ended, wide-ranging discussions with group leaders and group members as well as field staff of promoter agencies, and visits to the bank and the Block Development Office (BDO). My aim was to to observe first-hand the processes that preceded the sanction and disbursal of bank loans.

\section{SHGs in the study villages}

In the three study villages, the SHGs were exclusively women's groups, with age ranging from three to seven years. The number of members per SHG ranged from 16 to 20 . Of the 27 SHGs, 15 were composed exclusively of the Scheduled Castes (SCs) and 10 of the Other Backward Classes (OBCs), while 2 SHGs had members of both caste groups. ${ }^{6}$ While each SHG had a savings account with its nearest bank branch, the 27 SHGs were promoted by diverse agencies that included development NGOs, the BDO and the rural branch of a nationalized commercial bank. Table 1 shows the distribution in the study villages of all SHGs, those that had received the SGSY financial (loan-cum-subsidy) assistance and those that had received the Direct Linkage loan.

Table 1: SHG distribution in study villages

\begin{tabular}{|l|r|r|r|r|}
\hline & Village 1 & Village 2 & Village 3 & Total \\
\hline Total No of SHGs studied & 10 & 8 & 9 & 27 \\
\hline $\begin{array}{l}\text { Of total, SHGs that received } \\
\text { SGSY assistance }\end{array}$ & 5 & 6 & 2 & 13 \\
\hline $\begin{array}{l}\text { Of total, SHGs sanctioned (not } \\
\text { disbursed) SGSY assistance }\end{array}$ & - & - & 2 & 2 \\
\hline $\begin{array}{l}\text { Of total, SHGs that received the } \\
\text { Direct Linkage loan }\end{array}$ & - & - & 9 & 9 \\
\hline
\end{tabular}

\footnotetext{
${ }^{5}$ While all relevant contextual information is provided, the names of the study villages, the administrative block and district and the promoter NGOs are withheld.

${ }^{6}$ For the most part, the two principal caste groups (SCs and OBCs) live in segregated fashion in separate hamlets in rural Tamil Nadu. Hence, most SHGs are also caste-segregated.
} 
The total financial assistance ranged from Rs.50,000 to Rs.200,000 per SHG for the 15 groups that received or were sanctioned the SGSY loan. Of this, the subsidy component ranged from one-third to one-half of total loan value. The amount of the Direct Linkage loan received by the 9 SHGs ranged from Rs.40,000 to Rs.200,000 per SHG.

\section{Poverty, Social Context, and 'Financial Intermediation'}

The women members of SHGs were expected to constitute themselves as responsible savers and disciplined borrowers who demonstrated to banks - through the efficient rotation of their own capital - that they were fiscally responsible agents qualifying for bank credit. The information in the SHGs' books of accounts (the savings pass books and loan ledgers) on the repayment status of all loans borrowed by the women informed the judgments of bank officials regarding the creditworthiness of the group as a collective and of individual members. Conscious that SHG-banking linked them to women from households and communities that had been the targets of 'social banking'-type schemes associated with poor credit discipline in the past, ${ }^{7}$ the financing banks were found reluctant to make loans through the Linkage scheme which carried no lending quota. Consequently, the bank personnel subjected the SHGs' account books to intense scrutiny whenever women sought loans through the scheme. The NGOs that engaged in SHG promotion in other parts of Tamil Nadu also testified that the zero tolerance displayed by some bank managers towards any delay in the repayment of internal loans disadvantaged groups comprising very poor and socially marginalized communities when they applied for the Linkage loans. In contrast, the 'anti-poverty' mandate of the SGSY scheme and its disbursal targets to vulnerable social groups mediated bankers' credit-assessment procedures.

In the three study villages, the women attempted to make the bank officials understand that irregular repayment (of internal loans) was, to an extent, inevitable due to poverty and uncertain livelihoods. More commonly, women altered SHG account books before bank supervision to create a semblance of timely repayment. The promoter NGO played the critical role of 'setting right' the account books by camouflaging repayment irregularities prior to bank evaluation of SHGs' loan ledgers. Directly promoted by the financing bank, the nine SHGs in village 3 were deprived of this dimension of 'promotional' support. When the five SHGs comprising women of the OBC communities in village 3 received a loan of Rs.200,000 per group through the Linkage scheme, the four SHGs located in the Scheduled Caste habitation of the village applied for the loan as well. Arguing that the 'irregular' repayment of their internal loans demonstrated diminished capacity to repay bank loans, the bank manager firmly turned them away. ${ }^{8}$ One of the more tenacious of the four SHGs was sanctioned a (smaller) sum of Rs.150,000 after the women "wore down" the manager through their repeated visits and requests. Eventually the other three SHGs in the SC habitation were also sanctioned the Linkage loan after a change of guard at the bank. The President of one of the SHGs commented, "The former manager was too strict in judging our repayment record. But the new man has a conscience and is more humane. He understands our poverty."

Interestingly, the women did not always concede the bank's right to govern their financial decision-making through evaluation, and thus regulation, of their responses to livelihood and other crises. The President of an SC SHG in village 3 challenged the manager (who had denied their Linkage loan) saying, "We have no employment now and have not

\footnotetext{
7 Poor institutional incentives for repayment had plagued older, credit-based anti-poverty schemes also implemented by commercial banks (Kabeer and Murthy 1996).

${ }^{8}$ As per current rates, approximately Rupees $60=1$ US $\$$
} 
repaid our loans. But it is our savings money that we haven't repaid. And that is not your business. You have a right to question us if we don't repay your loans. When the bank officers brought to bear an intense scrutiny of their internal loan repayment, women from the poorest SHGs drew attention to the economic oppression of their households and communities. They framed their entitlement to the Linkage scheme not in terms of their fiscal performance, but rather the dire nature of their need for development resources from the state. They reminded the bank officials that household poverty and the vagaries of livelihoods inevitably mediated the forms of financial intermediation their SHGs displayed.

\section{Fabricating Entrepreneurship: The Costs and the Gains}

World-systems theorists analyzing household structures in the capitalist world-system argue that the structural importance of subsistence work and petty production for the survival of poor households signals an incomplete or semi-proletarianization, with wages constituting only part of the incomes on which these households rely (Wallerstein and Smith 1984). In the three villages studied, the households of SHG members were engaged in a range of petty market activities that involved both petty commodity production and micro-scale retail or trade, which supplemented incomes from (seasonally-available) wage work in the farm and non-farm sectors. The vast majority of these market-oriented activities may be classified as "survival activities" (Ghate, Ballon and Manalo 1996) into which the poor are pushed for the want of more profitable activities. They involve rudimentary skills and low entry barriers and are over-crowded and clustered at the bottom of the informal sector. Some of the most common examples in the region of study were home-based beedi $i^{9}$-rolling, vegetable, fruit and flower vending, mobile door-to-door sales of cooked food, and petty hawking.

A few of the other remunerative activities, that were regarded as commercial successes in the context of the village economy, may be classified as 'micro-enterprises' wherein experience and skill requirements restricted entry. While micro-enterprises, in contrast to survival activities, are generally seen to generate savings for expansion and potential for growth (Ghate, Ballon and Manalo 1996), this was not always the case in these villages. Most of the micro-enterprises in question (such as shops, grocery stores or hotels) were home-based (with the front portion of the house serving as the premise for the activity), catered to village-specific markets, and survived through the intensive exploitation of family labor-usually comprising the SHG member and her husband. ${ }^{10}$ The owners of these homebased shops or hotels contributed to the profitability of larger, wholesale stores and shops in the neighboring towns from which they sourced their wares, but they hardly, if ever, maintained detailed financial accounts of their own businesses and often drew on their stock to feed and supply provisions to their households. While the loans sourced from SHGs were used to supplement working capital for these small businesses, their owners ruled out any possibility of re-investment of their earnings to grow the business either through investing in new technologies, expanding the scale of operation, shifting their unit to the nearest town, or hiring waged (i.e., non-household) labor. The only prospect of capital-intensive business activity offered to the SHG members in these villages was the invitation from the state to participate in the SGSY scheme.

\footnotetext{
${ }^{9}$ Beedis are low-cost, hand-rolled cigarettes.

${ }^{10}$ None of the women in the villages of study participated in sub-contracted production chains that accumulated capital and derived profits by linking women's home-based income-earning activities to global or overseas markets. A classic example of this instance may be found in Maria Mies' (1981) description of Indian 'housewives' making lace for global export markets.
} 
In April 1999, the SGSY was introduced as the outcome of a policy decision to consolidate multiple extant self-employment promotion programs into a single comprehensive scheme, based on a group approach, in contrast to the earlier focus on the individual beneficiary (RBI 2011). By way of addressing some of the shortcomings associated with pre-existing programs, the SGSY guidelines prescribed that (a) development resources be concentrated in developing a few selected economic activities in a block and that (b) the rural development administration, commercial banks, and the Panchayat ${ }^{11}$ collaboratively undertake comprehensive planning to ensure the viability of enterprise activities selected under the scheme (RBI 2011). The SHGs that received the SGSY loan were expected to set up group-owned and managed enterprises, selecting from the list of activities pre-approved in each block.

In the study villages, the women members of the SHGs dismissed as far-fetched and impractical the underlying premise of SGSY policy viz., the posited linear relationship between enterprise activity managed by the rural poor (organized into SHGs) and the generation of business incomes that would enable them to cross the income-poverty line. In particular, the women rejected in toto the idea of group-owned, capital-intensive and statefinanced micro-enterprises, or the particular entrepreneurship model advanced by the SGSY scheme. This had as much to do with the absence of support from the rural development administration in sourcing markets for the proposed new enterprises as the saturation of local village markets by existing small businesses and the perceived non-viability of groupmanaged business activity.

Nonetheless, the SGSY scheme was much sought after on account of the coveted subsidy component, which induced women to make the scheme work for them by subverting its official borrowing purpose. Rather than being invested in a group enterprise, in 11 of 13 SHGs that received the loan, the loan-cum-subsidy amount (following group practices with internal loans or Linkage loans) was equally distributed amongst the members and used for a variety of household-related needs. ${ }^{12}$ The loan was repaid to the bank, not through business incomes as envisioned by policy, but through incomes earned by the SHG women and their earning household members via multiple forms of wage and self-employment.

Even as the women repudiated the official borrowing purpose of the SGSY loan package, they strove to sustain the myth of 'women's entrepreneurship' financed by the scheme. The case of an SHG, which proposed to manage a brick kiln business, illustrates the modus operandus involving a three-way nexus between the SHG, the bank and a local business owner. The SHG contacted a brick kiln owner in the neighborhood and struck a deal with him. The owner provided documentary evidence to the bank stating that the SHG had acquired a brick kiln and leased it to him to manage. The SHG women paid the brick kiln owner Rs.4000 for providing the document and extending his cooperation. Bank staff inspected the brick kiln thrice for purposes of verification and photo documentation. However, as the Secretary of the SHG put it: "Of course the bank knew that we were not managing the brick kiln!" Importantly, the fiction of make-believe enterprises was created and sustained by the SHGs with the full knowledge of promoter NGOs, financing banks and the subsidy-sanctioning $B D O$. This collusion was rendered necessary by the mandate of all agencies to ensure that an annual quota of loans allocated under the scheme was disbursed to women who were neither willing nor able to engage in loan-financed income generation.

The enterprise activities that the SHGs proposed to manage included poultry farming, the leasing of coconut groves, tailoring units, shoe-making units, brick kilns, manure preparation, mosaic stone making and coir (rope) making units. In each case, the back-door

\footnotetext{
${ }^{11}$ The Panchayat is the lowest unit of local self-governance in India.

${ }^{12}$ The two groups that were sanctioned, but had not yet received the loan also planned to do the same.
} 
entry of locally based and small-scale business operators was crucial to sustaining SGSY policy on the field. Identifying willing enterprise owners was difficult and the pay-offs correspondingly high if the owners feared a possible seizure of their enterprise by the bank, in case of a loan default by the group. The expenses incurred by SHGs did not always end with the disbursal of the loan. SHGs were required to participate in government-sponsored exhibitions of SHG products that celebrated the emergence of women 'micro-entrepreneurs' and SGSY-promoted livelihoods. Such exhibitions demanded that the fiction of managing enterprises be sustained over a longer period and at higher cost.

The women valued the SGSY scheme despite the costs, the stress, and the efforts involved in the complex and often conflict-ridden negotiations that preceded loan sanction and disbursal. SHGs had no control over timing of bank loan sanction. Hence, bank loans were used to fulfill the long-term needs, distinct from immediate or emergent needs of households such as the acquisition of assets, gold jewelry in particular, the repayment of old debt, and improvements to housing. The women also used bank loans to seek elective medical treatment for chronic, long-term conditions, in contrast to the internal loans that were used to finance treatment for medical emergencies or sudden illness.

The value that women attached to the 'successful' implementation of the SGSY scheme was reflected in their extraordinary efforts to ensure disciplined, on-time loan repayment. The misgivings of bank officials regarding women's ability or intent to repay bank loans were belied by on-time repayment of all bank loans (whether subsidy or nonsubsidy) by all SHGs. The repayment discipline was sustained through punitive practices such as the verbal abuse of borrowers (by co-members), the imposition of fines for late repayment, and the quicker-than-necessary repayment of bank loans. Defaulting on a bank loan was inconceivable, no matter the circumstances.

\section{Invoking the State: Beyond 'Financial Inclusion'}

A significant non-material resource that the SHGs presented was the opportunity to network closely with state agencies and build strategic relationships, which were drawn upon by women to advance interests that extended well beyond access to low-cost bank credit or antipoverty schemes. The SHGs in Tamil Nadu functioned as a state-legitimized, village-level organizational structure that represented women at public forums from which they were customarily excluded as individuals. On the orders of the state government, SHGs were routinely invited to participate in all public events relating to local governance, such as the village-level Panchayat meetings. The links that the women's groups developed with state institutions were invaluable insofar as they enabled the women to navigate local vested interests and caste-based power structures. In one of the villages, the traditional (unelected) village headman was incensed at the women (and women of the socially marginalized castes, in particular) for their participation in the village-level public meeting (Grama Sabha) of the Panchayat, and he challenged their right to do so. The SHGs promptly reported the matter to the chief of the rural development administration (the District Collector), on whose orders the officials of the BDO and police personnel rebuked the headman for over-stepping the limits of his jurisdiction.

As this case suggests, the women proactively used the official support for their SHGs to gain access to other state institutions, in particular the police. It was uniformly reported that police stations were more willing to register cases of sexual harassment, marital violence, and dowry-related abuse when these were referred by the SHGs. Some women reported that they used the threat of "filing a complaint using the SHG letterhead" to reign in abusive husbands or sons-in-law. My interviews with men revealed that rural communities popularly 
interpreted the presence of multiple state actors in SHG promotion and financing as support for an agenda of gender equality. The disgruntled husband of an SHG member informed me that the government had made the "big mistake" of declaring that "women are equal to men" through its support for women's SHGs. The exhibitions organized by the local administration to showcase enterprises financed by the SGSY scheme served to reinforce the perception that women's social status and power as a collective had grown since the advent of SHGs. It did not matter that the SHGs did not actually own or operate the enterprises on display because the exhibition served as a visible manifestation of women's access to state institutions and public spaces and a powerful means to convey a sense of what women could achieve.

\section{Conclusion}

This paper has explored the simultaneously intertwined and divergent trajectories of the feminized SHG phenomenon and an emergent neoliberal capitalism in India. It situates this with respect to broader structural compatibilities between microfinance/credit based development interventions and capitalist accumulation on a world scale. The frontiers of formal finance in India have moved "down market" (Von Pischke 2003) via SHGs to the women of rural land-poor households and socially oppressed castes that did not previously have access to the formal financial sector, despite the inclusive promise of 'social banking' and its endeavors to reach the financially excludedpoor. However, the highest echelons of India's policy making institutions, such as the RBI, NABARD and the Ministry of Rural Development, have designed 'inclusive banking' and 'anti-poverty' projects that make women's economic entitlements contingent on their appropriate financial behavior and the display of 'disciplined' financial intermediation. Despite the relative autonomy that SHGs enjoy as 'micro-banks' (Harper 2002) that generate their own capital and decide the terms of group transactions, they function nevertheless under the watchful gaze of the state via promoter NGOs, the rural development administration, and nationalized commercial banks.

If microfinance strives to produce "rational economic" actors (Karim 2011; Rankin 2001) who efficiently participate in the new "self-regulating" markets that it creates (Weber 2002), the SHG phenomenon requires that women imbibe the skills, capacities and entrepreneurial subjectivities deemed necessary, and that they engage in (self and peer) disciplining in order to successfully advance the agenda of financial deepening at village levels. We might understand the SHG-targeted SGSY scheme as part of the Indian state's endeavors to increase the reliance of rural poor households on self-employment activities that are sufficiently capital-intensive and large-scale enough to enable them to cope with economic adversity without making additional demands of the state or private capital. The SHG phenomenon itself might be seen as an emergent technology of neoliberal governmentality that aims to autonomize and responsibilize rural poor communities, who are being urged to take over some of the functions of the state through generating local employment and increasing profits for small enterprises (Rose 1999: 174; Miller and Rose 1990; Ferguson and Gupta 2002).

However, as my fieldwork suggests, the long-term transitions that the liberalizing state has attempted to initiate at household and community levels have had uneven and partial effects, involving conflict, collaboration, collusion, and even outright subversion. The women members of SHGs laid claim to bank credit even when they did not adhere to the professed objectives and formal rules of the schemes through which they availed state developmental resources. The women of socially oppressed castes coaxed, cajoled, beseeched and argued with bank managers to secure access to the Direct Linkage loans, even if the repayment record of their internal loans was judged and found wanting. Despite their outright rejection 
of the enterprise-management clause, the women in all the SHGs that applied for the SGSY loan finance sought what they perceived as their rightful entitlement to the financial assistance it entailed.

In the latter instance, the women converted state support for micro-enterprise development to a form of government transfer or welfare provisioning through their (labor, cost, and effort-intensive) appropriation of the SGSY scheme, strengthening, thereby, the safety net (Karides 2010; Weber 2002) component of SHG-based microfinance. Although expected to cultivate disciplined repayment performance by the bank managers they interacted with, the women vigorously defended their right to permit flexibility and latitude with respect to the repayment schedules of their internal or group-generated loans. However, they recognized that the disciplinary dynamics that accompanied bank loans were of a different kind altogether. Resorting to punitive disciplinary mechanisms, the women bent over backwards to repay bank loans, offering the advantage of a new, hyper-disciplined and feminized clientele to commercial banks operating in a performance-oriented and portfolioconscious 'reform' environment.

While Weber (2002) expects that the political safety net function of microfinance will dampen/ contain political mobilization or popular protests that challenge neoliberal policies at the grassroots, the women, on the contrary, used the platform provided by the SHGs to bring to the attention of state representatives their anger and despair at the deplorable working conditions that prevailed in the lower rungs of the informal sector in which they were employed. During the monthly block-level meetings ${ }^{13}$ organized by promoter NGOs and attended by government representatives, the women raised issues relating to the unsanitary work environment of leather-processing industries, the pitiably low wages offered by the smaller shoe companies, the Rs.10-a-day wage that home-based beedi work earned, and the verbal abuse and sexual exploitation of women workers (of the subordinate castes) in the construction sector by the (mostly dominant caste) site supervisors.

Refusing to confine their concerns to the self-employment oriented micro-enterprise activities that were deemed the exclusive business of the SHGs, the women persistently drew attention to all the sites in which they labored. They urged the state to legislate effectively in order to increase the monetary returns to their labor in the informal sector and to re-structure their everyday work lives in ways that would attenuate its oppressive dimensions. In so doing, the women demanded, in effect, a "re-embedding of the economy within social and political control" (Weber 2002) and sought to hold the state to account for its evident disinterest in doing so. We see therefore that while SHG-based microfinance seeks to govern the subjects of development-rural women from land-poor households-bringing them in line with mainstream financial practices and constituting them as disciplined neoliberal subjects, the dissenting 'counter-conducts' of the women and the collusive nexus they create with the agents of the state demonstrate the "variegated" and "ambiguous" terrain on which financial governance proceeds, the "decentered" and "heterogeneous" practices that constitute it, and the uneven effects it generates (Aitken 2010: 237).

The women's responses to the SHG phenomenon that I have mapped in this paper suggest that we are witnessing a complex re-configuring of the relationship between the liberalizing state and rural households and communities in India. It is evident that these women have eschewed a position of thoroughgoing opposition to the state, given the valuable, survival-oriented resources it offers. Equally importantly, this reflects their experience-derived recognition of what feminist scholars have reiterated in multiple contexts - that the state can be a valuable ally for women who negotiate multiple patriarchies

\footnotetext{
${ }^{13}$ These meetings were held to discuss the routine management and smooth functioning of SHGs and the repayment of bank loans.
} 
embedded within family/kin relationships and at broader community levels (Sangari 2007; Rai 2008). If the SHG women and their households are not attempting a radical dissociation from a statist agenda of financial governance, they do not give up resistance to (some) elements of neoliberal governmental rationalities that conflict with the survival imperatives of their households either. As women's SHGs continue to remain central to the anti-poverty initiatives of the central government in India ${ }^{14}$ it remains to be seen what new strategies women in poverty will devise to wrest development resources from the state, even while they may (or may not) fully or partially reform their conduct and fashion themselves in keeping with policy expectations. The question of whether women's struggles "in and against the state" (Rai 2008: 56) as they play out in the evolving terrain of SHG-based microfinance will continue to marshal 'allies' from local state agents in order to sustain challenges to caste, household and kin-based patriarchies is one that remains equally open-ended.

Self-help programs such as the Indian microfinance case are one instance of contemporary state-led initiatives in the capitalist world-system to autonomize and responsibilize households and communities in ways that render them efficient actors who survive adversities and utilize, with entrepreneurial zeal, the new market opportunities ostensibly opened up by neoliberal reforms. In order, however, that we understand the longterm transitions in the capitalist accumulation strategies they set in motion and capture more fully the contradictions and complex, often unintended outcomes they generate, academic research must create spaces whereby theoretical literatures on the capitalist world-system and neoliberal governmentalities are allowed to inflect and engage with each other's perspectives and concerns. Perhaps through such creative engagements we might delineate better the emergent local face of neoliberalism in many parts of the world, the political contests it has generated, and the gendered characteristics it often bears.

\section{References}

Aitken, Rob. 2010. "Ambiguous Incorporations: Microfinance and Global Governmentality." Global Networks 10 (2): 223-243.

Bhaduri, A. 1986. "Forced Commerce and Agrarian Growth." World Development 14(2): 267-72.

Bhaduri, A. 1973. "A Study in Agricultural Backwardness under Semi-Feudalism." Economic Journal 83 (329): 120-37.

Burchell, G. 1996. 'Liberal Government and Techniques of the Self'. Pp 19-36 in Foucault and Political Reason: Liberalism, Neoliberalism and Rationalities of Government edited by Andrew Barry, Thomas Osborne and Nikolas Rose. Chicago: The University of Chicago Press.

Chatterjee, P. 2008. "Democracy and Economic Transformation in India." Economic and Political Weekly 43(16): 53-62.

Chatterjee, P. 1998. "Development Planning and the Indian State." Pp 82-103 in The State, Development Planning and Liberalization in India edited by Terence J. Byres. Delhi: Oxford University Press.

Corbridge, S., J. Harriss, S. Ruparelia, and S. Reddy. 2011. "Introduction: India's Transforming Political Economy', Pp 1-16 in Understanding India's New Political

\footnotetext{
${ }^{14}$ While the SGSY scheme is in the process of being phased out and replaced by the National Rural Livelihoods Mission (NRLM), the latter also seeks to incorporate women's microfinance SHGs within the ambit of its programs. Its stated aim is to bring a woman from each identified rural poor household under the SHG network as part of a 'universal social mobilization' strategy it espouses (MoRD n.d: 8).
} 
Economy: A great transformation? edited by Sanjay Ruparelia, Sanjay Reddy, John Harriss and Stuart Corbridge. London and New York: Routledge.

Ferguson, J. and A. Gupta. 2002. "Spatializing States: Toward an Ethnography of Neoliberal Governmentality." American Ethnologist 29 (4): 981-1002.

Ghate, P., E. Ballon and V. Manalo. 1996. "Poverty Alleviation and Enterprise Development: The Need for a Differentiated Approach." Journal of International Development 8 (2): 163-178.

Gonzalez-Vega, C. 2003. "Deepening Rural Financial Markets: Macroeconomic, Policy and Political Dimensions." Paper for "Paving the way forward: An international conference on best practices in Rural Finance.' Washington D.C., 2-4 June, 2003.

Gupta, A. and K. Sivaramakrishnan. 2011. "Introduction: The State in India after Liberalization", Pp 1-27 in The State in India after Liberalization: Interdisciplinary Perspectives edited by Akhil Gupta and K. Sivaramakrishnan. London and New York: Routledge.

Harper, M. 2002. "Self-help Groups and Grameen Bank Groups: What are the differences?" Pp 169 - 198 in Beyond Micro-Credit: Putting Development Back into MicroFinance, edited by Thomas Fisher and M. S. Sriram. New Delhi: Vistaar Publications and UK: Oxfam.

Harriss, J. 2011. "How far have India's economic reforms been 'guided by compassion and justice'? Social policy in the neoliberal era" Pp 127-139 in Understanding India's New Political Economy: A great transformation? edited by Sanjay Ruparelia, Sanjay Reddy, John Harriss and Stuart Corbridge. London and New York: Routledge.

Hulme, D. and P. Mosley. 1996. Finance against Poverty. Volume 1. London and New York: Routledge.

Jackson, C. 1996. "Rescuing Gender from the Poverty Trap." World Development 24 (3): 489-504.

Johnson, S., and Ben Rogaly. 1997. "Microfinance and Poverty Reduction." UK and Ireland, Oxfam and ACTIONAID.

Kabeer, N., and Ranjani K.Murthy. 1996. "Compensating for Institutional Exclusion? Lessons from Indian Government and Non-Government Credit Interventions for the Poor". Sussex: Institute of Development Studies, Discussion Paper - 356.

Karides, Marina. 2010. "Theorizing the Rise of Microenterprise Development in Caribbean Context." Journal of World Systems Research 16 (2): 192-216

Karim, L., 2011. "Microfinance and its Discontents: Women in Debt in Bangladesh" University of Minnesota Press.

Kohli, R. 1997. "Directed Credit and Financial Reform." Economic and Political Weekly 32 (42): $2667-2676$.

Mayoux, L. 2002. "Women's Empowerment or Feminization of Debt? Towards a New Agenda in African Micro Finance." Report based on a One World Action Conference. London, March 2002. Available:

http://www.womankind.org.uk/wp-content/uploads/2011/10/49. Womens-Empowerment-orFeminisation-of-Debt1.pdf. Accessed 17 March 2015

Mies, M., 1981. "Dynamics of sexual division of labour and capital accumulation: Women lace workers of Narsapur." Economic and Political Weekly 16 (10/12): 487-500.

Miller, P. and N. Rose 1990. 'Governing Economic Life', Economy and Society, 19 (1): 1-31

Ministry of Rural Development (MoRD) n.d. "National Rural Livelihoods Mission: Framework for Implementation." Government of India. Available: http://rural.nic.in/sites/downloads/latest/NRLM_23122010.pdf Accessed 17 March, 2015 
Murray, J. and R. Rosenberg. 2006. "Community-managed Loan Funds: Which Ones Work?" Small Enterprise Development, 17 (3): 13-27

NABARD. 2013. "Status of Microfinance in India 2012-2013." Micro Credit Innovations Department, Mumbai: National Bank for Agriculture and Rural Development.

NABARD. 2006. "Progress of SHG Bank Linkage in India 2005-06." Mumbai: National Bank for Agriculture and Rural Development

NABARD. 2005. "Annual Report 2004-2005." Mumbai: National Bank for Agriculture and Rural Development.

NABARD. 2002. "Guidelines for the Pilot Project for linking banks with Self Help Groups', Circular dated 26 February, 1992, Development Policy Department: National Bank for Agriculture and Rural Development.

NABARD. 1999. 'Microfinance Scenario in the Country,' (Chapter 1) in Task Force on Supportive Policy and Regulatory Framework for Microfinance, Report. Mumbai: National Bank for Agriculture and Rural Development

Pagura, M. and M. Kirsten. 2006. "Formal-informal Financial Linkages: Lessons from Developing Countries." Small Enterprise Development 17(1): 16-29

Polanyi, Karl. 1957. The Great Transformation: The Political and Economic Origins of Our Time. Boston: Beacon Press.

Prahalad C.K. 2005. The Fortune at the Bottom of the Pyramid: Eradicating Poverty through Profits. New Jersey, Upper Saddle River: Prentice Hall.

Pulley, Robert V. 1989. "Making the Poor Creditworthy: A Case Study of the Integrated Rural Development Program in India." World Bank Discussion Papers, Washington DC: The World Bank

Rai, Shirin M. 2008. The Gender Politics of Development. New Delhi: Zubaan and London and New York: Zed Books

Rankin, K.N. 2001. "Governing Development: Neoliberalism, Microcredit and Rational Economic Woman." Economy and Society 30 (1):18-37.

Razavi, S. 1997. "Fitting Gender into Development Institutions." World Development 25(7): $1111-1125$.

Reserve Bank of India. 2011. Master Circular on Priority Sector Lending - Special Programs - SGSY. (http://rbi.org.in/scripts/BS ViewMasCirculardetails.aspx?Id=6557\&Mode=0) Accessed 17 March, 2015

Reserve Bank of India. 2009. "Master Circular on Micro Credit", Available: (http://rbidocs.rbi.org.in/rdocs/notification/PDFs/40MCMC010709 F.pdf). Accessed 17 March, 2015

Rose, N. 1999. The Powers of Freedom: Reframing Political Thought. Cambridge: Cambridge University Press.

Sangari, K. 2007. "Shaping Pressures and Symbolic Horizons: The Women's Movement in India" Pp 36-67 in At the Cutting Edge: Essays in Honour of Kumari Jayawardena edited by Neloufer De Mel and Selvy Thiruchandran. New Delhi: Women Unlimited.

Subramaniam, M. 2015. "Introduction: States and Social Movements in the Modern WorldSystem" Journal of World Systems Research.

Thomas, Caroline. 2000. Global Governance, Development and Human Security: The Challenge of Poverty and Inequality. London: Pluto Press.

Vasavi A.R., and Catherine P. Kingfisher. 2003. "Poor Women as Economic Agents." Indian Journal of Gender Studies 10 (1): 1-24.

Von Pischke, J.D. 2003. 'The Evolution of Institutional Issues in Rural Finance: Outreach, Risk Management and Sustainability', Paper for 'Paving the Way Forward for Rural 
Finance: An International Conference on Best Practices', Washington D.C., 2-4 June, 2003.

Wallerstein, Immanuel and Joan Smith. 1984. "Core-periphery and Household Structures" Pp. 253-262 in Households and the World Economy edited by J. Smith, I. Wallerstein, and H. Evers. Newbury Park: Sage Publications.

Wallerstein, Immanuel. 2004. World-Systems Analysis: An Introduction. Durham and London: Duke University Press.

Weber, H. 2002. "The Imposition of a Global Development Architecture: The Example of Microcredit." Review of International Studies 28 (3): 537-555.

Wenner, Mark D.1995. "Group Credit: A means to Improve Information Transfer and Loan Repayment Performance." Journal of Development Studies 32(2): 263-281.

Yunus, Muhammad. 2005. "Eliminating Poverty through Market-based Social Entrepreneurship." Global Urban Development Magazine 1(1). Available:

http://www.globalurban.org/Issue1PIMag05/Yunus\%20article.htm Accessed 17 March 2015 